\title{
Sustainable Development and Global Responsibility in Corporate Governance
}

\author{
Daniela M. Salvioni ${ }^{*}$ Riccardo Astori ${ }^{* *}$
}

\begin{abstract}
The sustainable development and the global corporate responsibility have emerged recently as relevant factors both at a business level and with reference to the society in general.

Global markets impose new and complex systems of corporate governance aimed at a generic retrieval of effectiveness if compared to the growing dynamism and to the gradual increase of complex relations between company and environment. In this regard the sustainable development represents an important issue, whose implementation requires the adoption of a suitable orientation of the governance policy, the diffusion of ethics principles and values common to corporate network, the adoption of efficient systems of risks prevention and internal control. This article aims at investigating the current interrelationship between corporate governance and global responsibility, as conditions for sustainable development. In particular, the article aims at highlighting - at theoretical and empirical level - the growing cross-relationship between effectiveness and economic and socialenvironmental efficiency, necessary conditions to minimize risks and to obtain success in the medium-long term.
\end{abstract}

Keywords: Global Responsibility; Sustainable Development; Corporate Governance; Risk Management; Internal Control; Key Factors of Success

\section{Global Responsibility and Stakeholder Relation Management}

For a long time, the choices of corporate governance have been oriented to the satisfaction of shareholders' expectations, they have been aimed at maximum profit, sometimes with significant differences among the subgroups of contributors of risk capital (for example in insider systems, between majority and minority shareholders).

\footnotetext{
*Full Professor of Business Administration, University of Brescia (salvioni@eco.unibs.it)

** Research Fellow in Business Administration, University of Brescia (astori@eco.unibs.it)
} Corporate Governance, Symphonya. Emerging Issues in Management (symphonya.unimib.it), n. 1, 2013, pp. 28-52 
Recently, it has affirmed a new approach to the companies' role in the society. This was due to growing frauds or to poor business management, but also to emerging new concepts of sustainable development around the world and of managing the relationships with the stakeholders. (Steurer, Langer, Konrad, Martinuzzi 2005).

Naturally, corporate sustainability does not mean loss of importance in the creation of value and of adequate remuneration of risk capital contributors. On the contrary it is appropriate to emphasize the interdependence among stakeholder relation management, economic social and environmental responsibility, results (economic and otherwise), capability of obtaining consensus and resources. It is evident, in fact, a governance approach that aims at increasing the shareholders abilities of creating values over time through the exploitation of opportunities and management of social and environmental risks, which companies currently have to compare with. (Esty, Winston 2008).

A company oriented to sustainable development is clearly aware of its responsibilities towards different stakeholders and adopts methods and tools of governance aimed at improving its economic, social and green/ecologic performances. It is an approach based on a wide vision of responsibility, on a modern interpretation of the links between the long-lasting company success and the equal composition of all stakeholders' interests. (Salvioni 2003; Salvioni, Bosetti 2006).

In global markets the need of improving the approach to company governance has emerged according to a logic system directed to: the appropriate emphasis on the competitive orientation in all markets of interaction (market-driven management) (Brondoni 2003; Brondoni 2009); the enhancement of the close relationships between managing variables in the economic, competitive and social-environmental field; the development of strategies of prevention and control of the risks (Salvioni 2012).

The company ability of knowledge and innovation has been taking on an increasing importance in order to maintain the conditions for the success, it increases the need of activating specific competitive abilities and it reduces the time of evaluation processes.

The participation in a more efficient resource-oriented economy, which is environmental oriented and competitive, implies significant changes in the complexity of relationships with relevant company stakeholders. On the other hand, the diffusion of knowledge highlights the potential increase of information and of conducting analyses on advantages compared by the stakeholders.

The integration between economic and social-environmental purposes change the decisional variables, emphasizing the interdependence among economic, social and environmental responsibilities in order to optimize the results compared to the stakeholder expectations.

Successful companies are currently working at adopting, maintaining and strengthening coherent systems of governance with best practices international standards. They are able to manage complex business and relevant conditions for the sustainable development. In this regard, the effectiveness of the governance is significantly influenced by the adoption of policies that emphasise the principles of global responsibility, positive and equal interaction with the stakeholders and respect towards the environment. 
The policy of governance concerns the vision, the mission, the aims and the main company purposes. The transformation of guidelines for sustainability into actual outcomes implies the adoption of suitable tools and processes that guarantee its constant implementation. In this context, the assumptions below have a relevant importance:

- preparation of code of ethics and dissemination of ethical principles and values common to the company network;

- adoption of effective risks management and internal control systems aimed at ensuring the correct development of strategic decisions that have been taken, in order to minimize risks and maximize results.

The growing importance, given to the affirmation of a governance oriented to global responsibility and stakeholder relation management, involves a greater attention to the principles and values that dominate the internal and external relations; as well as the innovation of the projects aimed at guaranteeing a systematic, coordinated, effective and efficient orientation to sustainable development. In this sense, it has recently witnessed a proliferation of international recommendations and numerous national regulatory interventions, which have promoted an increasing focus - especially by bigger and listed companies- on the quality of the governance.

With reference to the importance given by UE to the sustainable development, it is particularly relevant to consider the choices taken by companies working in several European countries in order to check uniformity of behaviour and the effective results of stakeholder relation management orientation in a sustainable development perspective. In this regard, the article examines the top ten capitalized companies of: England (outsider system country and one-part system of corporate governance); Germany (insider system country and two-parts vertical model of corporate governance according to the Rhine type); Italy (insider system country and dominance of two-parts horizontal model of corporate governance).

The choice of the most capitalized companies (Table 1) responds to the need of valuating primarily the behaviour of the companies leader in their respective stock markets: large and global corporations, subjected to stronger regulatory measures and market controls that require transparency to the stakeholders.

In order to evaluate the effectiveness of communication to stakeholders in a global perspective, the analysis of the company was based on data and information published in English on websites. In particular, reference was made to the code of ethics and/or of conduct, as well as the last report of corporate governance and the annual financial published report ${ }^{1}$. 
Table 1: Companies under Investigation (Capitalisation Values at 28.03.2013)

\begin{tabular}{|c|c|c|c|c|c|}
\hline \multicolumn{2}{|c|}{ ITALY } & \multicolumn{2}{|c|}{ GERMANY } & \multicolumn{2}{|c|}{ ENGLAND } \\
\hline Name & $\begin{array}{l}\text { Capitalisation } \\
\text { (MLN euro) }\end{array}$ & Name & $\begin{array}{c}\text { Capitalisation } \\
\text { (MLN euro) }\end{array}$ & Name & $\begin{array}{l}\text { Capitalisation } \\
\text { (MLN euro) }\end{array}$ \\
\hline Eni & $64.079,67$ & SAP & $74.891,49$ & Bhp Billiton & $154.466,74$ \\
\hline Enel & $24.019,68$ & Siemens & $70.847,00$ & $\mathrm{Bp}$ & $135.192,71$ \\
\hline Unicredit & $19.373,13$ & Volkswagen & $68.332,96$ & $\begin{array}{l}\text { Royal Bank of } \\
\text { Scotland Group }\end{array}$ & $132.908,05$ \\
\hline $\begin{array}{l}\text { Assicurazioni } \\
\text { Generali }\end{array}$ & $19.064,92$ & Bayer & $66.545,61$ & Hsbc Holdings & $131.261,42$ \\
\hline $\begin{array}{l}\text { Intesa San } \\
\text { Paolo }\end{array}$ & $18.831,39$ & Basf & $62.958,25$ & $\begin{array}{l}\text { British American } \\
\text { Tobacco }\end{array}$ & $103.195,87$ \\
\hline $\begin{array}{l}\text { Luxottica } \\
\text { Group }\end{array}$ & $18.594,11$ & Allianz & $47.973,52$ & Vodafone Group & $91.766,60$ \\
\hline Tenaris & $18.439,77$ & BMW & $44.150,28$ & Unilever & $78.839,37$ \\
\hline Snam & $12.065,86$ & Daimler & $42.993,20$ & GlaxoSmithKline & $74.526,41$ \\
\hline Saipem & $10.622,08$ & $\begin{array}{l}\text { Deutsche } \\
\text { Telekom }\end{array}$ & $35.461,62$ & Rio Tinto & $56.999,25$ \\
\hline $\begin{array}{l}\text { Telecom } \\
\text { Italia }\end{array}$ & $10.299,21$ & $\begin{array}{l}\text { Deutsche } \\
\text { Bank }\end{array}$ & $28.253,49$ & SABMiller & $52.036,33$ \\
\hline
\end{tabular}

\section{Code of Ethics and Sustainable Development}

The adoption of code of ethics and/or of conducts distinguishes the best practices of corporate governance.

The codes of ethics considers the principles and values as basis of the company responsibilities, which are shared by organization and aim at integrating business activities respecting and protecting all the stakeholders' interests, whom the company interacts with, with the preservation of environmental resources and their conservation for future generations. It deals with the rules of orientation to sustainable development that should represent an essential reference in the future of the company's activity.

The globalization of markets has brought: on the one hand, the affirmation of general principles of correctness in the company governance, often formalized in codes of ethics and conducts; on the other hand the affirmed importance of sharing these principles with own stakeholders, with dissemination and participation of the organization and of main external partners.

With reference to the transparency of the codes, it is relevant their edition in the company website clearly, precisely and comprehensive (Table 2$)^{2}$, in addition to the subscription by the main operating stakeholders.

Table 2: Level of Transparency on the Code of Ethics

\begin{tabular}{|l|c|c|c|}
\hline & Italy & German & England \\
\hline $\begin{array}{l}\text { Edition of the code of ethics/ ethics of Behaviour (in } \\
\text { English) }\end{array}$ & $100 \%$ & $100 \%$ & $90 \%$ \\
\hline
\end{tabular}

The orientation of sustainable development also involves the declination of principles and rules of behaviour with respect to compatible environmental performances and to different kinds of social actors, whom the company interacts 
with. In this regard, the analysis of the published codes highlighted the frequent presence of expressive variables of sustainability, even though with some qualitative differences between companies and countries (Table 3 ).

Table 3: Level of Orientation to Sustainability

\begin{tabular}{|l|c|c|c|}
\hline & Italy & German & England (*) \\
\hline Environment & $60 \%$ & $80 \%$ & $67 \%$ \\
\hline & & & \\
\hline Shareholders & $90 \%$ & $50 \%$ & $44 \%$ \\
\hline Management, employees and associates & $100 \%$ & $100 \%$ & $89 \%$ \\
\hline Suppliers and associates & $90 \%$ & $60 \%$ & $67 \%$ \\
\hline Customers and consumers & $90 \%$ & $70 \%$ & $78 \%$ \\
\hline Competitors & $50 \%$ & $70 \%$ & $78 \%$ \\
\hline Local communities & $70 \%$ & $60 \%$ & $78 \%$ \\
\hline Political organizations and unions & $80 \%$ & $60 \%$ & $100 \%$ \\
\hline Authorities and Public Institutions & $70 \%$ & $50 \%$ & $78 \%$ \\
\hline
\end{tabular}

(*) Data referred to the 9 companies which have the code.

The enhancement of ethic dimension of environment protection has increased in parallel with the affirmation of global responsibility, even though with significant differences related to the activity sector and to ecological impact.

$\square$ For example, Volkswagen group - German corporate that produces cars - highlights in its code: "We bear responsibility for continuous improvement of the environmental tolerability of our products and for the lowering of demands on natural resources while taking economic considerations into account. We therefore make ecologically efficient advanced technologies available throughout the world and implement them over the entire lifecycle of our products. At all of our locations, we are a partner to society and politics with respect to the configuration of social and ecologically sustainable positive development. Each of our employees make appropriate and economical use of natural resources and ensure that their activities have only as limited an influence on the environment as possible."

The adoption of a governance approach, based on rules which take the sustainability into account, takes on a specific relevance with regard to the internal and external net of relationships in order to facilitate the creation of virtuous circles between the stakeholders' expectations, company behaviours and results.

Overall, the range of the stakeholders categories contemplated in ethic codes is quite large. This number is, however, sterile if we do not consider the specific dimensions which different principles are faced with, in relation to each category. In this sense, the link between standard privileged behaviours and relevant stakeholders' classes. is significant. 


\section{Standard Behaviours and Stakeholder Relation Management}

The role of the codes of ethics for the effectiveness of relationships with the stakeholders, depends on the relevant behaviour principles compared with the different social actors who interact with the company. With this regard, it is necessary to consider the standard behaviour for each category.

\section{a) Shareholders}

In the last ten years the European Union has implemented intervention in order to promote a corporate governance that protects shareholders' rights, facilitate relationships between shareholders and corporate governance boards and protect the third parties3. In particular, UE has intervened on transparency promoting the improvement of the relations with the stakeholders and firstly, with the shareholders.

The codes of ethics seem to reflect the community guidelines, provided that the standards behaviours which are privileged at the level of relationship with the stakeholders emphasise participation, transparency of information and information symmetry (Table 4).

Table 4: Standard Behaviours in the Relations with the Shareholders.

\begin{tabular}{|c|c|c|c|}
\hline & Italy & German & England \\
\hline Facilitate the participation & $50 \%$ & $0 \%$ & $0 \%$ \\
\hline Transparency of information & $70 \%$ & $60 \%$ & $78 \%$ \\
\hline $\begin{array}{l}\text { Information symmetry and information management } \\
\text { (insider trading, internal dealing, Market abuse) }\end{array}$ & $90 \%$ & $80 \%$ & $78 \%$ \\
\hline
\end{tabular}

Most of the codes contains the rules of managing the external communication which must be true, comprehensive, timely and available. These features are not always cited in code of ethics but they sometimes relate references to truthfulness and/or timeliness of information. Substantially, it is common the reference to the need of respecting the rule that guides the treatment of price sensitive information and market communication.

Typically Italian is the declaration of promoting the participation of shareholders in the company life.

SNAM underlines in its code: "The internal structure of Snam and the relations with the parties directly and indirectly taking part in its activities are organised according to rules able to ensure management reliability and a fair balance between the management's powers and the interests of shareholders and of the other Stakeholders in general as well as transparency and market traceability of management decisions and general corporate events which may considerably influence the market value of the financial instruments issued. Snam deems it necessary that shareholders are enabled to participate in decisions which come within the limits of their competence and make informed choices. Therefore, Snam undertakes to ensure maximum transparency and timeliness of information communicated to shareholders and to the market - by means of the corporate internet site, too - in compliance with the laws and regulations applicable to listed companies." 


\section{b) Management and employees}

The standard behaviours in relationship with managers and employees mainly regard: healthcare and safety at work; promotion of human resources training; adoption of criteria for selection and carrier based on the logic of merit; the appreciation of the differences among people; the prohibition of harassment and bullying/mobbing (Table 5).

Table 5: Standard Behaviour in Relationship with Management and Employees.

\begin{tabular}{|c|c|c|c|}
\hline & Italy & German & England \\
\hline Healthcare and safety at work & $90 \%$ & $80 \%$ & $78 \%$ \\
\hline Training promotion & $40 \%$ & $10 \%$ & $22 \%$ \\
\hline Merit system criteria and carrier & $90 \%$ & $30 \%$ & $44 \%$ \\
\hline Policy against discrimination & $90 \%$ & $70 \%$ & $67 \%$ \\
\hline Policy against harassment and bullying & $70 \%$ & $40 \%$ & $67 \%$ \\
\hline
\end{tabular}

It is useful to consider that, as regards the involvement in the employees' governance, Germany differs from Italy and England. It is a country where comanagement exists, for which workers are involved in the mandate of governance. This situation shows a different relationship with the employees, that doesn't highlight relevant discrepancies in the standard behaviour.

In general, it is frequently the respect of the Universal Declaration of Human Rights rejecting child labour and highlighting the commitment to promote better working conditions.

In three cases (Intesa San Paolo, Enel e Deutsche Telekom) the company marks the desire to promote policies that are in favour of a balance between personal and professional life of the employees, requesting the managers to verify the adequacy of tasks and assigned activities. In one case (Royal Bank of Scotland) it is also referred to situations of stress at work which must be evaluated and avoided.

A company (Enel) establishes also the policy of intervention in case of reorganization of work activities, safeguarding the value of human resources through training and/or professional retraining activities and uniform distribution, where possible, of reorganization of tasks.

$\square$ So Enel said in his code of ethics: "In cases where work activities are reorganised, the value of human resources must be safeguarded by undertaking, wherever necessary, training and/or professional retraining activities. To this end, Enel follows the criteria listed below:

- the burden of work reorganisation must be distributed as evenly as possible between all employees, so as to ensure an effective and efficient performance of the Group's activities;

- in cases where new or unforeseen situations have to be dealt with, the employee may be assigned to tasks which differ from those performed previously, though care must be taken to ensure that his or her professional capacity is safeguarded."

$70 \%$ of UK societies (against 50\% Italian and $20 \%$ German) points out the problem of alcohol and drugs abuse. In some cases the companies are willing to provide the necessary medical and psychological assistance, besides highlighting 
the negative effects on health and possible consequences in terms of sanctions, when the problem is reflected at the workplace.

For example, BHP Billiton affirms in his behaviour code: "In line with our commitment to providing a safe and healthy work environment, while at work or when conducting Company business, employees must be able to function at an acceptable level of performance and not be impaired by illegal or legal drugs, including alcohol. Alcohol must not be offered or consumed at any BHP Billiton site, including an office or operational site, with the exception of operations that offer on-site 'wet messes' or canteens as part of the need for social facilities that are not otherwise available. Functions held at a BHP Billiton site, even if they occur out of working hours, must be alcohol-free.

If you consume alcohol at a 'wet mess' or off-site during a workday or rostered work period, whether at a BHP Billiton function or not, you must not return to work until the next work day or the next rostered work period, at the earliest or until such later time as you are fully fit for duty. As a general rule BHP Billiton prohibits smoking in all its buildings. At some sites smoking is permitted in designated smoking areas. To prevent exposure to passive smoking a designated smoking area must be clearly identified, sealed off from any adjacent areas and properly ventilated. BHP Billiton also prohibits the possession or use of illegal substances on BHP Billiton premises, at BHP Billiton functions or in conjunction with any BHP Billiton business dealing. Most BHP Billiton businesses have introduced drug testing, as well as support programs to assist employees with alcohol and drug dependencies. Repeated poor work performance caused by alcohol or drug use, or impairment that creates a safety risk, may amount to misconduct."

\section{c) Supplier}

Standard behaviours in relationships with suppliers tend to emphasize the criteria for selecting suppliers and the willingness to share their ethics within the supply chain (Table 6).

Table 6: Standard Behaviour in Relationship with Suppliers

\begin{tabular}{|l|c|c|c|}
\hline & Italy & German & England \\
\hline Criteria of selection of suppliers & $90 \%$ & $50 \%$ & $56 \%$ \\
\hline Sharing of code of ethics & $60 \%$ & $40 \%$ & $67 \%$ \\
\hline
\end{tabular}

As regards the choice of suppliers the reference emphasizes the criteria of transparent, efficient and effective selection, based on specific skills aimed at establishing and maintaining these long-term collaborations. In this regard, Enel also states the adoption of procedures that ensure the rotation of people responsible for supply.

- In fact, Enel explains in its code of ethics: "The signing of a contract with a supplier must always be based on extremely clear 
relationships, avoiding, wherever possible, forms of dependence. For example:

- it is improper to convince a supplier to enter into a disadvantageous contract by holding out the possibility of a more advantageous contract in the future;

- as a rule, binding, long-term projects with short-term contracts that require continuous renewals involving price revisions are avoided, as are consulting contracts that do not include an adequate transfer of know-how etc.;

- special care must be taken with the drawing up and management of contracts the estimated value of which is particularly significant in relation to the supplier's business volume.

To guarantee the utmost transparency and efficiency in the purchasing process, periodical rotation of staff assigned to purchasing is encouraged and the following measures are also implemented:

- the separation of roles between the unit requesting the supply and the unit signing the contract;

- adequate capacity to track the decisions made;

- keeping of information, together with official tender and contractual documents, for the periods established under the regulations currently in force and referred to in the internal purchasing procedures."

Moreover, given the critical nature of relationship with suppliers, some companies adopt to specific codes.

$\square$ Vodafone underlines in its code: "We base all of our procurement on our code of Ethical Purchasing. This commitment ensures that we consider the wider impact our business has on communities, society and the environment. We also want our suppliers, contractors and third parties to comply with our code, and we work closely with them to make sure our standards are an integral part of their own operations and supply chains."

d) Customers and consumers

Key principles in managing the relationships with customers are mainly related to the correctness of commercial policies, quality of products/services offered as well as to the completeness and accuracy of information provided.

Table 7: Standard Behaviour in Relationship with Customers and Consumers.

\begin{tabular}{|c|c|c|c|}
\hline & Italy & German & England \\
\hline Correctness of commercial policies & $80 \%$ & $60 \%$ & $56 \%$ \\
\hline Quality of not harmful products & $50 \%$ & $20 \%$ & $11 \%$ \\
\hline Completeness and accuracy of products information & $70 \%$ & $50 \%$ & $33 \%$ \\
\hline
\end{tabular}

For example, Telecom Italia underlines: "The excellence of Group companies' products and services is founded on the attention paid to customers and the willingness to satisfy their requests. The ultimate aim must be to guarantee an immediate, capable and competent response to 
customers' needs, through conduct based on business correctness, transparent relationships and contractual commitments, as well as on courtesy and cooperation, in any case without using any statement harmful to the business image of competitors, in compliance with customers' central role and disciplinary principles based on specific internal procedures."

The German company, Allianz stated: "When establishing a customer relationship or providing financial services to a client, appropriate care shall be taken that the customer receives information which is necessary for a reasonable decision by the customer be it as part of the product information or be it through the advising intermediary or producer. Which information or advice are necessary depends on the service, the product and the expertise of the categories of clients involved, as well as the applicable market standard. The same applies to whether and which information must be asked from the client as requirement for advice."

Glaxosmithkline PLC explains: "Product information at both the country and global level must comply with the company's medical position on product labelling, and be supported by accurate, evidence based information. All pharmaceutical marketing and promotional activities, and supporting promotional materials by GSK companies worldwide must conform to high ethical, medical, and scientific standards.”

e) Competitors

Relationships with competitors are mentioned in $50 \%$ of Italian codes, $70 \%$ of German codes and 67\% UK codes (Table 8).

Table 8: Standard Conduct/Behaviour in Relationships with Competitors

\begin{tabular}{|l|c|c|c|}
\hline & Italy & Germany & England \\
\hline Fair competition & $50 \%$ & $70 \%$ & $67 \%$ \\
\hline
\end{tabular}

Relationships with competitors are often fairness oriented and appreciate the competitive success through the merit of their results. It is often referred to antitrust rules and prohibition to implement agreements with competitors for fixing prices or achieving goals otherwise not pursued. Sometimes it is referred to policies that prohibit the abuse of dominant position, the imposition of restrictions to suppliers and customers at the expense of competition, as well as the realization of joints and acquisitions which may harm the image and the reputation of the company.

In Siemens' business conduct guidelines, it is stated: "Fair competition permits markets to develop freely - with attendant social benefits. Accordingly, the principle of fairness also applies to competition for market share. Every employee is obliged to abide by the rules of fair competition. Anti-trust evaluation can be difficult, particularly because the rules can differ from country to country and from case to case. For example, in many places special anti-trust law 
requirements apply to large companies. Here are examples of the types of behaviour that can lead to a violation of antitrust laws. Employees may not:

- talk to competitors about prices, output, capacities, sales, bids, profits, profit margins, costs, methods of distribution or any other parameter that determines or influences the Company's competitive behaviour with the aim to solicit parallel behaviour from the competitor,

- enter into an agreement with a competitor not to compete, to restrict dealings with suppliers, to submit bogus offers for bidding or to divide up customers, markets, territories or production programs,

- have any influence on the resale prices charged by our purchasers, or attempt to make them restrict the export or import of goods supplied by Siemens. Moreover, employees may not obtain competitive intelligence by using industrial espionage, bribery, theft or electronic eavesdropping, or communicate knowingly false information about a competitor or its products or services."

British American Tobacco underline: "Group companies must seek to compete fairly and ethically and within the framework of applicable 'competition' laws (or 'anti-trust' laws, as they are known in certain countries) wherever in the world they operate."

f) Local communities

Relationships with local communities are ruled in the code of ethics, respecting the local rights and with awareness of the existing relationships (Table 9).

Table 9: Standard Behaviours in Relationships with Local Communities

\begin{tabular}{|l|c|c|c|}
\hline & Italy & Germany & England \\
\hline Respect of local rights & $60 \%$ & $30 \%$ & $60 \%$ \\
\hline Philanthropic activities & $60 \%$ & $50 \%$ & $40 \%$ \\
\hline
\end{tabular}

The involvement of local communities in business activities and the promotion of relative consensus are possible through the companies willingness of promoting the territory, even with philanthropic activities. In this regard six out of ten Italian societies declare it.

Telecom Italia affirmed: "Group companies intend to contribute to the economic well-being and growth of the communities in which they operate by providing efficient and technologically advanced services.

Group companies must reserve donations in favour of third parties such as, in particular, non-profit organizations and entities - by taking concrete humanitarian and cultural, social and sporting initiatives, which may represent concrete actions to create added value for shareholders and stakeholders, also in terms of civil, in compliance with internal policies and procedures."

In Siemens code it is read: "As a responsible member of society, Siemens makes monetary or product donations for education and science, art and culture, and social and humanitarian projects. 
Sponsorships for which Siemens receives advertising are not considered donations, nor are contributions to industry associations or fees for memberships in organizations that serve business interests. Some donations are always prohibited, including donations: 1. to individuals and for-profit organizations; 2. paid to private accounts; 3 . to organizations whose goals are incompatible with Siemens' corporate principles, or 4. that would damage Siemens' reputation. All donations must be transparent. This means, among other things, that the recipient's identity and planned use of the donation must be clear and the reason and purpose for the donation must be justifiable and documented. Quasi-donations, meaning donations which appear to be compensation for a service but are substantially larger than the value of the service, are prohibited as violating the principles of transparency."

Glaxosmithkline underlines: "We also aim to make a positive difference to the communities in which we operate through economic contribution, investment, education programmes and partnerships."

\section{g) Political organizations}

Relations with political organizations are often accepted in codes, especially in the Anglo-Saxon outsider systems (Table 10).

Table 10: Standard Behaviour in Relations with Political Organizations

\begin{tabular}{|c|c|c|c|}
\hline & Italy & Germany & England \\
\hline Policy of distribution of donations to political parties. & $70 \%$ & $60 \%$ & $100 \%$ \\
\hline
\end{tabular}

As regards the relations with the political organizations, declarations about the behaviour of companies towards financing the parties are particularly relevant. These declarations are commonly present, especially in the codes of ethics of UK companies, and tend to report the exclusion of the company from any form of financing the parties. In some companies, however, financing the party is accepted in compliance with specific and/or internal regulatory limits, not expressed in the codes of ethics. The management of relationships with the political parties requires respect of each worker's political idea, to whom, according to his/her role, is precluded to express an opinion which, even indirectly, can be traced to the company.

$\square$ For example: Saipem code establish "Saipem makes no direct or indirect contributions, in any form, to political parties, movements, committees, political organisations or trade unions, or to their representatives or candidates, except those specifically provided for under laws and regulations in force"; Basf code observed "BASF prohibits the use of corporate funds for contributions or payments to any political candidate for, or holder of, a political office"; Royal Bank of Scotland Group PLC's code highlighted "We recognise individuals may choose to become involved in political activities such as standing for national or local government. However, if you are involved in politics you have a responsibility to make sure this activity 
is kept entirely separate from your duties and that Group funds and resources are not used for political purposes."

\section{h) Authorities and Public Institutions}

With reference to the relations between companies and authorities and public institutions, the analysis of codes of ethics has marked the presence of declarations about the necessity of correctness, that must be maintained in the management of the relation and of transparency of information (Table 11). This principle is often accompanied by the definition of possible nature of the relationship, mainly due to the need to bring own interests and those of category to the attention of the authorities, cooperating constructively for the development of legislation and regulation.

Table 11: Standard Behaviour in Relationships with Authorities and Public Institutions

\begin{tabular}{|l|c|c|c|}
\hline & Italy & Germany & England \\
\hline Correctness in relationships & $70 \%$ & $50 \%$ & $67 \%$ \\
\hline Competence reserved to specific functions & $60 \%$ & $10 \%$ & $33 \%$ \\
\hline
\end{tabular}

Six out of ten Italian companies have also stated that the competence in managing these relations is exclusively reserved to specific functions, precluding every unauthorized person to establish relations with authorities and public institutions.

$\square$ Luxottica marked in its code of ethics: "Relations with public entities and bodies, which are necessary for the development of the Luxottica Group's company programs, are the sole prerogative of the company functions charged with this task. Relations are to be oriented towards the utmost transparency, clarity and propriety and such as not to result in partial, falsified, ambiguous or misleading interpretations by the public institutional exponents with whom relations are maintained in various capacities."

The analysis of codes of ethics underlines even values and rules of conduct which are transversal to the different categories of stakeholders (Table 12). In this field it may be numbered: policies which regulate the exclusive use of corporate assets and protection of tangible and intangible assets of the company; anti-money laundering and anti-terrorism policies, which need constant attention and monitoring activities from all operators involved; the regulatory policies of conflicts of interests, sometimes also with examples of possible cases; anti-corruption policies, active and passive, which commonly prohibit giving or accepting gifts, donations and benefits, except modest value gifts; the security policies of data and information, specifying privacy and retention requirements.

Table 12: Other Standard Behaviour

\begin{tabular}{|c|c|c|c|}
\hline & Italy & Germany & England \\
\hline Policy of use and protection of the corporate's assets & $70 \%$ & $80 \%$ & $89 \%$ \\
\hline Anti-laundering policy & $10 \%$ & $40 \%$ & $33 \%$ \\
\hline Anti-terrorism policy & $10 \%$ & $20 \%$ & $22 \%$ \\
\hline
\end{tabular}




\begin{tabular}{|l|c|c|c|}
\hline Policies for regulating the conflicts of interests & $100 \%$ & $100 \%$ & $100 \%$ \\
\hline Anti-corruption policies & $80 \%$ & $100 \%$ & $100 \%$ \\
\hline Protection of privacy and security of information & $100 \%$ & $100 \%$ & $89 \%$ \\
\hline
\end{tabular}

$\square$ For example, as regards the policies of protection of the corporate's asset: Assicurazioni Generali underline: "The Group tangible assets, including real estate, equipment and supplies, must be protected from damage and misuse and must be used for working purpose only, unless properly authorized. Business-related information, including any acquired in the performance of assignments on behalf of the Group, shall be treated as confidential. Employees must hundle it with strict confidentiality and disclose it only on a need-to-know basis or if specifically authorized. The same rules apply to all documents containing such confidential information. Group intellectual property must be protected, if appropriate, also through patents, trademarks and copyrights"; Bayer highlighted "Invention, patents and other intellectual property are the "reward" for our endeavors and expenditures in the areas of research and development. They are extremely important to our company's future, as are our brands, the value of which may in some cases be substantial and the result of decades of effort and marketing expenditures. We must therefore take utmost care to ensure that our rights in the property we create enjoy full legal protection. Trade secrets and new knowledge should not be passed on to third parties, much less made public, without the proper legal protection. The same care must be taken with information shared over the company's intranet. No employee may create or dispose of Bayer intellectual property (for example: patents; marks, particularly trademarks; utility models and designs; copyrights) or execute an agreement or otherwise exercise discretionary authority over such property without the express written consent of the specialist corporate units responsible for these matters (Law, Patents \& Licensing). Care should be taken to avoid any unintentional transfer of intellectual property through the negligent handling of company information in public, such as working with laptop computers in full view of others or making casual comments in public or in presentations. Business data must be protected against unauthorized access by third parties. No employee may make copies of business papers or data files other than for work-related purposes. Employees must respect the valid, legally recognized property rights of third parties and may not use them without permission. Employees may not use items belonging to Bayer for their own personal purposes or remove such items from company premises without their supervisor's express consent. Likewise, no data, programs or company papers may be copied or removed from the company's premises without approval...”; British American Tobacco affirmed: "Group companies and employees must take care to ensure that Group assets are not damaged, misused, misappropriated or wasted. Employees should report the abuse or misappropriation of Group assets by others. Theft or other fraudulent activity by employees is liable to result in immediate dismissal and prosecution after referral 
to the appropriate authorities. Employees must not use any company equipment or facilities for their personal activities, save in the limited circumstances set out below and subject always to any applicable policy or procedures concerning the use of company equipment which may be in place from time-to-time".

Standard behaviours are flanked by instructions for the proper implementation of the code (Table 13), reference point for risk management system and internal control.

Table 13: The Implementation Details of Code Conditions

\begin{tabular}{|l|c|c|c|}
\hline & Italy & Germany & England \\
\hline $\begin{array}{l}\text { Promotion of the knowledge and diffusion of the } \\
\text { codes of ethics }\end{array}$ & $70 \%$ & $50 \%$ & $56 \%$ \\
\hline Details of the reference organization and supervision & $90 \%$ & $90 \%$ & $78 \%$ \\
\hline Forecast of reporting system and complaint & $80 \%$ & $80 \%$ & $100 \%$ \\
\hline Penalty system & $70 \%$ & $90 \%$ & $78 \%$ \\
\hline
\end{tabular}

\section{Monitoring and Effectiveness of Governance}

The necessity of a conscious and rational governance, aimed at transferring value and principles of sustainability in behaviour and business results, does not end with formalization and diffusion of ethics and behaviour codes. For this purpose, it is necessary to activate tools and processes directed to control the risks and to govern behaviours at all levels in the organization.

Governance processes find a good support from risk management and internal control systems. These systems provide the elements of decisional relief, give validity to the intermediation role between stakeholders' expectations and operating behaviour, ensure compliance with internal regulations, completeness and transparency of communications coming from management and those directed outside (Salvioni 2003).

The top managers establish the guidelines for internal auditing in line with the company's needs, with the existing regulatory constraints and the internal and external complexity. The aim is to obtain proper diffusion of responsibility throughout the organization, maximizing the exploitation capacity of managerial opportunities and the abilities of contrasting threats, optimization of consistency between the expected and achieved results.

Every company must adopt a plurality of mechanisms of control coherent with the need due to the complexity, they are separated but necessary for the maintenance of the condition of effectiveness and widespread responsibility (Salvioni 2005).

The increasing importance of risks management and internal auditing systems has promoted, at the international level, the establishment of specific committees internal to corporate governance boards, which are responsible for propositive, consultative and supervision activities for the effective exercise of responsibility.

The introduction of committees for risks management and internal control facilitates the effectiveness of the government system related to the presence of members with qualities of independence, skillfulness and competence and professional ability. It is a connecting link between the corporate governance 
organization and the underlying system of governance for operational activities with the possibility to access to information and functions relevant for the own activity.

The control committees have numerous tasks, related to: the coordination of planning, implementation and management of the internal control systems; supervision on the proper definition of internal control procedures, according to instructions of corporate governance members; supervision on the effectiveness of the internal control processes (in particular internal auditing and risk management); and the proposal of changes based on the effectiveness of available tools and management procedures; expression of opinions, on request of the managers, on specific aspects concerning risk management; the checking of the requirements of independence, integrity and professionalism of the people involved in functions of internal and external control.

After having established a common acknowledgment of the importance of risks management and internal control for best practices of corporate governance, the implementation of control activity at the top level is different in relation to the governance system adopted. In the British system, the control functions are conferred to the audit committee, composed by non-executive independent directors of the board of directors. In the German system, the audit committee is established as committee of the control system, namely the supervisory board. The Italian twoparts system includes functions of control given to the audit committee - internal system of the board of directors - and to the statutory board. Hence the needs to define the function of each board and the relations between them guaranteeing effectiveness to the internal control system.

In the British and German companies the audit committee has to manage the reports concerning the non-compliance with the mandatory standards and internal procedures (compliance). In Italy, this function is typically entrusted to a Supervisory Board, introduced by Legislative Decree no. 231/2001.

The activity of control also involves constructive relations between boards and functions so as to ensure adequate flows of information and the coordination of the various activities in a systemic framework, according to the logic of effectiveness. In this context, relations are important with: governance authorities within which the committees are (board of directors or supervisory board), the authorities responsible for control (statutory board, audit companies, in charge of the internal control system), the internal auditing authorities (internal auditing, risk management, compliance).

$\square$ For example, in Luxottica "The Internal Control Committee meets whenever the Chairman deems it appropriate, usually prior to the Board meetings for the approval of the annual, six-monthly and quarterly reports, or whenever a meeting is requested to be called by him by another member. When the Committee deemed it necessary, the directors of the Company and the Luxottica Group were invited to participate in meetings to discuss specific items on the agenda and to review specifically the topics within their competence. The Committee has access to the information and the Company functions necessary for the performance of its task as well as to work with external consultants. The Board of Directors approved the allocation of funds totalling Euro 50,000 to the Committee for the 2011 fiscal year in order to provide it 
with the adequate financial resources to perform its tasks independently."

In Deutsche Bank "The Audit Committee is entitled to inspect all business documentation of the bank, including the business information stored on data carriers. The Audit Committee is entitled to obtain, in connection with its activities, information from the auditor, the Management Board and - with the consent of the Management Board senior managers of the bank reporting directly to the Management Board. For the performance of its duties, the Audit Committee may, at its professional discretion, use the services of auditors, legal advisors and other internal and external consultants. The costs are borne by the company. The Chairperson of the Audit Committee reports regularly to the Supervisory Board in plenum on the work of the Committee. The Audit Committee arranges to be informed regularly about the work done by internal audit, the effectiveness of the internal audit system and in particular about the areas of emphasis in its auditing activity and on the results of its audits. The Management Board informs the Audit Committee about special audits, substantial complaints and other exceptional measures on the part of German and foreign bank regulatory authorities."

In Unilever "The Audit Committee is authorised by the Board to investigate any matter within its terms of reference, using, at Unilever's expense, resources from within Unilever or from external legal, accounting or other advisers as the Committee considers necessary. The Committee is authorised to seek information from any Director, Senior Corporate Executive or employee, and from any adviser, agent or representative of Unilever, for the purpose of fulfilling its duties and the Board shall, if so requested, direct such persons to co-operate with the Committee. The Committee may form and delegate authority to subcommittees if the Committee feels appropriate. Any such sub-delegation shall be noted in the minutes of the Committee. The Committee meets at least four times a year, with authority to convene additional meetings as circumstances require. Meetings of the Committee may be attended by the Chief Executive Officer, Chief Financial Officer, Controller, Chief Auditor, Chief Legal Officer, the lead partner of the External Auditors, and other Directors and executives at the invitation of the Committee. The Committee shall meet the External Auditors in private session at least once a year and may also meet routinely in private sessions with any of the Chief Auditor, the external auditors, and management, or any combination of these....The Audit Committee reports to the Board by means of an oral presentation by the Committee Chairman the outcome of all its meetings and on how it has discharged its responsibilities. The Secretary prepares minutes of all meetings of the Committee and these are promptly circulated to the Committee and the Board for their consideration. The Committee reviews and assesses annually the adequacy of these Terms of Reference, and confirms that all the responsibilities set out in the current Terms of Reference have been carried out. The Committee ensures that its current Terms of Reference are made available on Unilever's external website." 
The Audit Committee is the main actor of an effective and constant approach by the whole organization to the proper management of global responsibility. The increasing in complexity of control dimensions, caused by the affirmation of logics of sustainable development, has determined the introduction of committee with more specific tasks. So, for example, almost all British companies analysed have internal committee for the corporate social responsibility. Also in the Italian context the social responsibility Committee is present (e.g. in Assicurazioni Generali); in Germany there aren't similar committees which are inside the supervisory board. However, in some cases, Governance Board has the functions of monitoring the sustainability for example, BMW states that the entire Board of Directors meets twice a year as Sustainability Board).

The diffusion of efficient committees in the corporate governance board, as well as structured ethic and behaviour codes, are a prerequisite that guarantees the realization of management oriented to sustainability. This prerequisite can permeate the corporate behaviour if there is a marked orientation to compliance and a constant monitoring of the relative implementation.

\section{Management of the Risks of Compliance}

Companies notice a growing risk of compliance, or the risk of non-conformity to the rules, to the regulatory, to procedure, to self-regulatory and to ethics and conducts code. Discrepancies between tasks of sustainability and results achieved, judicial or administrative sanctions, significant financial loss and significant damage to corporate's image can derive from the absence of appropriate tools of management, monitoring and auditing.

The number and the complexity of rules and self-regulatory system render appropriate the definition of organisational boards that ensure the respect, not only formal, of the prescriptions through: the identification of risks of non-conformity, definition of procedure of monitoring and control, the constant support and the counselling at management boards, the collaboration with other control boards, coordination and promotion of the activities of internal training on rules and regulations, as well as the sanctions system ${ }^{4}$. In this regards, a fundamental condition is the diffusion of ethic culture to all the organizational levels and the monitoring of the conformity of behaviour according with the principles and behaviour codes.

- For example, Intesa SanPaolo highlights "The Intesa SanPaolo Group undertakes to formulate and implement operative policies for each area of activity having significant ethical and reputational impact. Each company department preserves and guarantees the compliance of their actions and activities with the principles and values of the Code of Ethics. Every department is therefore directly responsible, within its own sphere of influence, for determining and formalising the goals, as well as the consequent plan of actions and projects, in order to give tangible meaning to the Principles of Conduct that dictate the Bank's behaviour in all of its relationships, even in a multi-stakeholder logic. Moreover, each department is responsible for carrying out the line 
controls in its own area of competence, identifying cases of noncompliance that might occur within its department and reporting them to the appropriate departments according to the procedures set up by the company. For the principle of self-responsibility to be effective, heads of Divisions/Offices shall appoint Corporate Social Responsibility (CSR) referees."

Bayer considers "The global nature of Bayer's operations means that our activities are subject to a wide variety of statutory regulations and standards throughout the world. That makes corporate compliance a particularly important topic for us - because corporate compliance means acting with integrity and observing the legal and ethical framework at all times. Corporate compliance is not an abstract concept, but a code of behavior that applies to everyone. It is valid for employees at all levels, in all parts of the Bayer Group and in all countries. Only by strictly adhering to these standards can we avoid significant legal and economic risks to our company, and thus to us all. And in this way we also preserve the legitimate interests of all our stakeholders - including customers, suppliers and shareholders - and respect the needs of society, such as the protection of people and the environment. Observing these rules at all times is therefore essential to maintain our pride in working for Bayer. And it is the only way we will gain society's acceptance of our business activities and achieve a sustained increase in corporate value. Bayer will forgo any business that would only be possible by violating the law or company rules.

BP explained in the annual report 2012 that: "Ethical misconduct or breaches of applicable laws or regulations could be damaging to our reputation, results of operations and shareholder value and could affect our licence to operate. Central to managing these risks is our code of conduct and our values and behaviours, the requirements of which apply to all employees, supported by our various group requirements covering issues such as antibribery and corruption, anti-money laundering, competition/anti-trust law compliance and trade sanctions. We seek to monitor for new regulations and legislation and plan our response to them. We also operate a range of compliance training and monitoring programmes for our employees, including OpenTalk, our confidential helpline for employees. In the normal course of business, we are subject to risks around our treasury and trading activities, which could arise from shortcomings or failures in our systems, risk management methodology, internal control processes or employees. In addressing these risks, we have adopted specific operating standards and control processes, including guidelines in relation to trading, and seek to monitor compliance through dedicated compliance organizations. We also seek to maintain a positive and collaborative relationship with regulators and the industry at large."

The government of compliance, actually, characterize all the well-managed companies. The relative effectiveness is essential for the implementation of behaviour oriented to sustainability, to integration between the managing, economic, social and environmental responsibility. It is conditio sine qua non for 
the sustainable development of companies, this involves the definition of an articulate system of risk management and internal auditing.

As regards risks management, the empirical analysis allowed to state uniformity in defining the typical phases of risk management: the definition of the pursued targets and, consequently, of acceptable risk level; the identification of internal and external events, that influence the achievement of the company's tasks and representative of factors of risks and opportunities; the evaluation of the probabilities of occurrence of events and connected impacts; the identification of actions - for prevention or after the manifestation of events - according to risks and opportunities; determination of controls on policies of contrast and prevention; monitoring the processes and the procedures adopted by the whole risk management system; the internal reporting activities and surveys carried out by people involved in the process.

$\square$ For example, in Annual Report 2012 of Eni it is highlighted "The IRM model is implemented through a process of integrated management which is both continuous and dynamic and leverages on the risk management systems already adopted by each business unit and corporate processes. This process includes risk assessment activities (identification, assessment and analysis), treatment, monitoring and reporting of risks. Starting from these and keeping account of their peculiarities and aims, specific tools and methodologies are applied. Based on the guidelines provided by the Board of Directors, the first step consists in the definition of the scope of risk assessment which targets the Company risks that might impact the achievement of corporate objectives (including sustainability initiatives) to the highest degree."

Deutsche Telekom stated "Our risk and opportunity management system is based on our standard process, starting with the definition of the desired risk profile. Once opportunities and risks have been identified, we move on to analyze and assess them in more detail. This also includes aggregating opportunities and risks depending on their probability of occurrence and magnitude. This is followed by a decision on the actual action to be taken (e.g., reducing risks/seizing opportunities). The associated action plan is implemented, constantly monitored, and evaluated. All steps are traversed again and again, and modified to reflect the latest developments and decisions. Our risk and opportunity management system covers all strategic, operational, and financial risks and opportunities. The aim is to identify these early on, monitor them, and manage them in accordance with the desired risk profile."

Glaxosmithkline underlined: "The internal control framework assists in the identification, evaluation, and management of significant risks as required by the UK Corporate Governance Code (UK Code) and is designed to manage rather than eliminate the risk of not achieving business objectives. The Framework provides reasonable, but not absolute assurance against material misstatement or loss. The Committee receives reports on areas of significant risk to the Group 
and on related internal controls. Following consideration of these reports and those received via the Assurance framework, the Committee reports annually to the Board on the effectiveness of controls."

The risk management system has naturally developed according to the organizational structure, taking into considerations the specific features of the sector and companies activity. In particular, it can be clearly perceived - even though with inevitable differences between the companies - the reflections of the organisational structure on the risk management system where it is expressly required peripherical functions and coordination between the societies of the group, the divisions and company functions.

$\square$ For example, in ENI "The objectives are articulated by business areas, organizational functions, functional areas, and when necessary by processes"; in Bayer "Risk management at the Group level is assigned to the Chief Financial Officer. The subgroups, service companies and the units of the holding company have nominated persons responsible for risk management at the upper managerial level as well as risk management coordinators to ensure that an effective system for the early identification of risks is implemented and maintained"; in Glaxosmithkline "The group Risk Management \& Insurance unit has central responsibility for the methods and systems used in an independent risk management system that has been standardized across the Group and for the associated reporting. The Risk Oversight and Compliance Council is a council of senior executives authorised by the Board to assist the Committee in overseeing the risk management and internal control activities of the Group”.

The type of risks identified by the analysed companies, is varied and articulated and reflects the characteristics of the sector, the strategies and the operating areas of each company. In this regards, however, the risks of compliance are relevant, generally they are considered specific case to be monitored but also elements that influence the general state of company's risks with significant effects on other kinds of risks (for example, risks in security and heritage safeguard, in integrity, in technology and computer).

In the Snam annual report 2012 it is stated: "Snam is required to comply with rules and regulations at EU, national, regional and local level. The expenses associated with the actions required to fulfil its obligations constitute a significant cost item now and for the years ahead. In addition to minimising the risks from its activities, compliance with rules and regulations is required in order to obtain authorisations and/or permits relating to health, safety and the environment. Violation of current regulations may result in criminal and/or civil sanctions and, in specific cases where safety and environmental rules are violated, companies may be liable on the basis of a European model of corporate social responsibility adopted in Italy by Legislative Decree 231/01. Snam may incur significant costs or 
liability. Current regulations highlight the value of organisational models aimed at preventing offences in the event of violation of environmental and workplace health and safety laws, specifying corporate social responsibility. Snam uses organisational instruments and internal regulations to establish the responsibilities and procedures to be adopted within Snam Group companies when designing, constructing, operating and disposing of all company assets, thereby ensuring compliance with laws and internal regulations on health, safety and the environment. Snam and the companies it controls have implemented environmental and workplace health and safety management systems based on the principles of its own Health, Safety, Environment and Quality Policy, which has been consolidated in the Company for several years. The documentation and application of the Snam Management Systems are certified according to international regulations."

In the "legal compliance code" of BMW, they specified: "It is essential for the success of our company to act responsibly and in compliance with the law. We, the members of the Management Board of $B M W A G$, set extremely high standards for our own actions and those of each and every employee of the BMW Group. This approach is integral to our corporate culture and is the reason why customers, shareholders, business partners and the general public place their trust in us. Even isolated violations of legal regulations could cause enormous damage to the BMW Group's excellent reputation which we work so hard each day to uphold. As a consequence, each one of you is obliged to act responsibly and in compliance with the law"

BHP Billiton annual report 2012 informed: "Our non-controlled assets may not comply with our standards. Some of our assets are controlled and managed by joint venture partners or by other companies. Management of our non-controlled assets may not comply with our management and operating standards, controls and procedures (including our HSEC standards). Failure to adopt equivalent standards, controls and procedures at these assets could lead to higher costs and reduced production and adversely impact our results and reputation".

"HSEC impacts, incidents or accidents and related regulations may adversely affect our people, operations and reputation or licence to operate”.

The risks of compliance are part of those risks defined preventable, which derive from internal phenomena of the organization, they are monitored and they can be avoided through the introduction of effective systems of control and insurance (Kaplan, Mikes 2012). In this regard it is essential to activate specific functions of control, that aim to interact in an indirect way with all the company's functions, in order to guarantee the constant alignment of internal rules, of processes and activities referred to the regulatory system that is applicable to codes of ethic and of behaviour.

In well-managed companies, the correct definition of principles and ethics values common to the organization and the rational link between code of ethic, policy of 
governance, risk management and internal control systems should facilitate a guidance which is systematic, coordinated, effective and efficient for the sustainable development.

\section{Emerging Issues}

The optimisation of the companies' abilities at creating a sustainable value is significantly influenced by: strategic importance given to integration of economic, social and environmental responsibility; diffusion and internal sharing of principles and values oriented to sustainability; activation of organic and complete risk management system; introduction of operative procedures planned, being aware of the risk level of violation that is innate in the activity and the introduction of the relative managing.

The codes of ethics, which are widespread at an international level and which are founded on principles and sustainable values, have the role of promoting behaviours oriented to global responsibility and to stakeholder relation management.

The diffusion of well-structured codes of ethics is common for most of the old industrialized countries and, even in regard with the contents of the different published documents, there aren't significant differences among societies, which work in legal context, in market and with system of different governance. The difference is visible among companies and in terms of codes, given that there are frequent cases of unrespectful behaviours of global responsibility, or they aimed at exclusively classes of stakeholders and their subgroups in relation to process production of outsourcing.

For example, the recent fall of Rana Plaza in Dacca, Bangladesh that provoked the death of hundreds of workers forced to work in harmful place, has discovered in the ruins the presence of numerous brand-companies with well-structured codes of ethics, formally (the Italian Benetton, the Swedish H\&M, the Irish Primark, the Canadian Joe Fresh, the American Wal-Mart). The survey on London Interbank Offered Rate (Libor) involved numerous big International banks, among which the Royal Bank of Scotland and Deutsche Bank that, as already observed, have wellstructured codes of ethics.

The codes of ethics represent the strategic value given to global responsibility, whose implementation requires transparency, sharing coherence of individual behaviour and control.

An effective structure of governance and control is for all companies a necessary condition to minimize the risks which may influence medium-long term success.

Given the growing importance of risk management system and internal control system for the sustainable companies' development, international best practises of governance have highlighted the opportunity of creating specific committees which are internal the corporate governance boards. They are responsible for activities of proposal, consultation and supervision. This choice is accompanied by structures and control processes that are more and more articulate, in this context compliance represents, at the same time, an element to monitor and a prerequisite of management effectiveness and it increases the possibilities of creating a sustainable value. 
The validity of risk management system and internal control system for the systematic, coordinated, effective and efficient towards the sustainable development orientation is conditioned by the ability of facing in advance the complexity in which the company works, through an integrated approach which aimed at valorising the culture of ethics and the global responsibility at corporate governance boards, at organization and at company network level.

In fact, in the recent years sustainable development and global corporate responsibility are relevant factors for the effectiveness of corporate governance. In this regard numerous international institutions intervened and companies, formally at least, increase their focus on the interdependence between stakeholder relation management, economic, social and environmental responsibility. But numerous and frequent scandals, which often involve companies, show how far they are from a situation where sustainable tasks transform into management behaviours.

\section{Bibliography}

Astori Riccardo, Bosetti Luisa (2010) Corporate Governance Systems Facing the Economic Crisis, 8Th International conference of management, Atene, pp 37-62 http://www.atiner.gr/docs/2011MGT-INTRO.pdf

Astori Riccardo, Cassano Raffaella, Gandini Giuseppina (2009) Structures of Corporate Governance in Italy and comparison at European level, International Review of Business Research Paper, vol. 5 , n. 1 , pp. 441-453

http://www.bizresearchpapers.com/35.Astori-Italy.pdf

Brondoni Silvio M. (2009) Market-Driven Management, Competitive Customer Value and Global Networks, Symphonya. Emerging Issues in Management (symphonya.unimib.it), n. 1, pp. 8-25. http://dx.doi.org/10.4468/2009.1.02brondoni

Brondoni Silvio M. (2003) Network Culture, Performance \& Corporate Responsibility, Symphonya. Emerging Issues in Management (symphonya.unimib.it), n. 1, pp. 8-24.

http://dx.doi.org/10.4468/2003.1.02brondoni

Carroll Archie B. (1993) Business and society: ethics and stakeholder management, South Western, Cincinnati.

Evan William and Freeman R. Edward (1993) A Stakeholder Theory of the Modern Corporation: A Kantian Capitalism, in T.L. Beauchamp, N.E. Bowie (eds), Ethical Theory and Business, Prentice Hall, New York.

Esty Daniel C., Winston Andrew S. (2008) Green to Gold: How Smart Companies use Environmental Strategy to Innovate, Create Value and Build Competitive Advantage, John Wiley publisher, New York.

Kaplan Robert S., Mikes Anette (2012) Managing Risks. A new Framework, Harvard Business Review, June.

Preston Lee E., Sachs Sybille (2002), Redefining Corporation, Stanford U.P., Stanford.

Salvioni Daniela M. (2012) Governance, Risk Management and Business Effectiveness in Global Firm, in Tipuric D., Dabic M. (eds.), Management, Governance, and Entrepreneurship. New Perspective and Challenges, Access Press UK, Darwen.

Salvioni Daniela M. (2005) Corporate Governance, Management Control and Global Competition, Symphonya. Emerging Issues in Management (symphonya.unimib.it), n. 1, pp. 39-51 http://dx.doi.org/10.4468/2005.1.03salvioni

Salvioni Daniela M. (2003) Corporate Governance and Global Responsibility, Symphonya. Emerging Issues in Management (symphonya.unimib.it), n. 1, pp. 44-54 http://dx.doi.org/10.4468/2003.1.05salvioni

Salvioni Daniela M., Bosetti Luisa (2006) Corporate Governance Report and Stakeholder View, Symphonya. Emerging Issues in Management (symphonya.unimib.it), n. 1, pp. 24-46 
http://dx.doi.org/10.4468/2006.1.03salvioni.Bosetti

Steurer Reinhard, Langer Markus E., Konrad Astrid, Martinuzzi Andrè (2005) Corporations, Stakeholders and Sustainable Development I: Theoretical Exploration of Business-Society Relations, Journal of Business Ethics.

http://dx.doi.org/10.1007/s10551-005-7054-0

\section{Notes}

1 The analysis has highlighted the absence of the document for an English company (Hsbc Holdings Plc), for which the information found on website weren't formalized in a document. As regards a German society, the code of ethics has been published on a specific webpage but it isn't downloadable for offline filing and accessing.

2 All values and principles of ethics and behaviour have been summed up by societies in "code of ethics" or "codes of conducts" except for two documents defined "codes of Compliance" and "Integrity codes".

3 V. The EU corporate governance framework, 2010, p. 3.

4 In Italy, the discipline of corporate compliance has been extended to all companies and organizations by Legislative Decree 231/2001, which extends beyond the traditional principle "Societas not criminal potest", establishes the administrative liability of entities. In particular, the legislation provides an exemption for companies that adopt an organizational control model liable to impede the fulfillment of defined crimes. 